\title{
A comparative trial of Rappaport enrichment medium for the isolation of Salmonellae from faeces
}

\author{
J. B. IVESON AND N. KOVACS ${ }^{1}$
}

From the Salmonella Investigation Unit, Public Health Laboratory Service, Perth, W.A.

SYNOPSIS Seven-thousand-and-thirty-six specimens of faeces were examined for Salmonellae using three enrichment culture media in parallel.

Rappaport's magnesium chloride malachite green broth medium proved superior to selenite $\mathrm{F}$ and tetrathionate broths in the recovery of a wide variety of Salmonella serotypes. However, it was inferior to selenite broth in the recovery of Salmonella typhi.

A higher recovery rate of Salmonellae was obtained from undiluted than from $1: 1,000$ dilution of faeces.

Combined selective and enrichment culture techniques are universally employed in the isolation of Salmonellae from a wide range of materials. Success in isolation, though influenced by a number of variables, ultimately depends on the efficiency of the medium used in its ability to differentiate, or to inhibit, the growth of non-pathogenic organisms particularly E. coli.

Over the years the selenite enrichment medium of Leifson (1936) and the tetrathionate broth of Müller (1923) have been widely used for the isolation of Salmonellae from faeces. Important modifications include the selenite broth of Hobbs and Allison (1945) and the tetrathionate broths of Kauffmann (1930, 1935), Rolfe (1946), Preuss (1949), Hajna and Damon (1956), and of Lang (1960).

In 1956 Rappaport, Konforti, and Navon introduced an enrichment broth containing magnesium chloride and malachite green. The medium appeared superior to selenite and tetrathionate broths in the recovery of Salmonella species, except Salm. typhi. Confirmation of their findings came from reports by Collard and Unwin (1958) and Hooper and Jenkins (1965). Iveson, Kovacs, and Laurie (1964), working with infected desiccated coconut, and Anderson and Kennedy (1965), using pure cultures, also reported the superiority of Rappaport's medium. The results of other workers differ: Sen (1964) obtained a higher Salmonellae yield in selenite broth, and Zajc-Satler

Received for publication 24 August 1966.

${ }^{1}$ Dr. N. Kovacs died on 25 September 1965. and Banič (1965) found increased isolations in tetrathionate medium prepared from infusion broth. However, both authors commented on Rappaport as being an efficient isolation medium.

In view of our findings with coconut and on the basis of preliminary trials on faecal specimens, it was decided, in 1961, to test the magnesium chloride malachite green broth in parallel with tetrathionate broth (Difco), the selenite broth of Leifson (1936), and, in a second series commencing in 1963, a modification of the tetrathionate broth of Preuss (1949).

\section{MATERIALS AND METHODS}

A total of 7,036 faeces specimens transported in $1 \mathrm{oz}$. bottles containing $2-5 \mathrm{~g}$. of faeces in $10 \mathrm{ml}$. of Sachs' (1939) enteric transport medium from patients with gastro-enteritis, or their contacts, resident in Western Australia, were examined at the Central Public Health Laboratories, Perth.

In series I, 407 specimens were tested in parallel, using the routine heavy inoculum and the 1:1,000 dilution of the specimen as recommended by Rappaport et al. (1956). In series II, omitting the dilute inoculum, comparative tests on 3,492 specimens using Rappaport, selenite (Leifson), and tetrathionate (Difco) media were performed; and in series III, 3,544 specimens were tested comparatively in Rappaport, selenite and Preuss' (1949) ' $\mathrm{K}$ ' tetrathionate by modified medium as Kovacs (1963). Direct selective culture was also performed on all specimens simultaneously with the enrichment procedures. Magnesium, chloride-malachite-green enrichment broth of Rappaport was prepared as follows: 
SOLUTION A

Bacto tryptone (Difco)

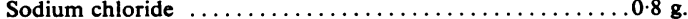

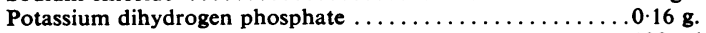

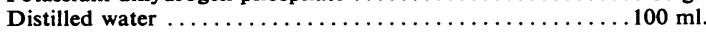

SOLUTION B

Magnesium chloride $\left(\mathrm{MgCl}_{2} .6 \mathrm{H}_{2} \mathrm{O}\right.$ A.R.) $\ldots \ldots \ldots \ldots \ldots \ldots \mathrm{g}$.

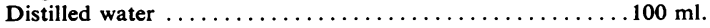

SOLUTION C

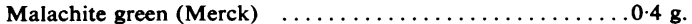

Distilled water .......................

For use, to each $100 \mathrm{ml}$. solution A, $10 \mathrm{ml}$. of solution $\mathrm{B}$, and $3 \mathrm{ml}$. of solution $\mathrm{C}$ were added. Throughout the investigations the medium was distributed in $10 \mathrm{ml}$. volumes in $1 \mathrm{oz}$. wide-neck, screw-cap bottles and sterilized by steaming for 30 minutes. No deterioration on storage at room temperature for at least one month was detected.

The ' $\mathrm{K}$ ' tetrathionate used in series III was prepared as follows:

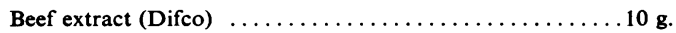

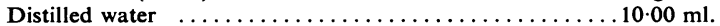

Sodium phosphate (anhydrous) $\mathrm{Na}_{2} \mathrm{HPO}, \ldots \ldots \ldots \ldots \ldots 1.6 \mathrm{~g}$.

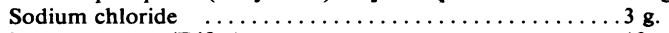

Bacto tryptone (Difco) ..........................

It was boiled, filtered, and brought to $p \mathrm{H} 6 \cdot 5$, autoclaved at $25 \mathrm{lb}$. for 15 minutes, and distributed in $50 \mathrm{ml}$. volumes, $0 \cdot 75 \mathrm{~g}$. potassium tetrathionate (Merck) powder was added, dissolved without heating, and distributed in $10 \mathrm{ml}$. volumes for use the same day.

Inoculations were made by sterile pasteur pipette. Approximately $1.0 \mathrm{ml}$. of mixed sample was sown into the $10 \mathrm{ml}$. volumes of enrichment media, and one drop plated directly on to McConkey, D.C.A. (Mackie and McCartney formulae), S.S. (Difco), and bismuth sulphite agar (Difco). Subcultures from enrichment media were made at 18 to 24 hours on to S.S. and bismuth sulphite agar. All plates were incubated at $37^{\circ} \mathrm{C}$. for 24 hours, bismuth sulphite agar being further incubated and examined at 48 hours. Non-lactose fermenters and colonies resembling salmonellae on B.S.A. were examined biochemically and identified serologically.

\section{RESULTS}

A total of 583 salmonella strains were isolated in the two main series reported (series II and III), of which 578 strains were isolated by enrichment culture procedures, and 238 by direct plating. Five strains were isolated only on direct plating, compared with 114 only through enrichment media; 75 of these came through Rappaport medium exclusively, 25 through selenite broth, and 14 through tetrathionate broth.

The serotypes recovered are listed below (the figures in brackets indicate the frequency of serotype isolations): S. typhimurium (237), S. muenchen (72), $S$. adelaide (18), S. saint paul (17), S. senftenburg (16), S. wandsbek (16), S. hvittingfoss (16), S. oranienburg (16), S. onderstepoort (15), S. wandsworth (13), S. chester (13), S. jangwani (10), $S$. tennessee (9), S. litchfield (9), S. eastbourne (9), $S$. orion (9), S. orientalis (8), S. poona (8), S. urbana (6), S. anatum (5), S. emmastad (4), S. welikada (4), $S$. abony (4), $S$. newington (4), S. bovis morbificans (3), S. derby (3), S. enteritidis (3), S. brisbane (3), $S$. paratyphi $B(3), S$. paratyphi $A(2), S$. kimberley (2), S. give (2), S. ohlestdt (2), S. san diego (2), $S$. bredeny (1), S. zehlendorf (1), S. lexington (1), $S$. california (1), S. alsterdorf (1), S. blukwa (1), S. charity (1), S. ball (1), S. potsdam (1), S. fremantle (1), S. champagne (1), Arizona group (2), S. unidentified (7). There appeared to be no special preference of a given serotype for a particular enrichment medium. A possible exception was Salmonella adelaide which was obtained from Rappaport medium on eight occasions in series III compared with 10 occasions from both selenite and tetrathionate broths. In series II, however, the figures were identical for all three media.

Specimens which had failed to yield Salmonellae on direct plating but which were positive on enrichment culture are shown in Table $I$, distributed by methods of enrichment. One hundred and twelve specimens proved positive on Rappaport medium compared with 95 and 75 respectively for selenite and tetrathionate only in series II. In series III the corresponding figures were 181,132 , and 121 respectively.

\section{TABLE I}

DISTRIBUTION OF DIRECT CULTURE NEGATIVE FAECES SPECIMENS YIELDING SALMONELLAE ON ENRICHMENT CULTURE RELATED TO COMBINATIONS OF METHODS USED

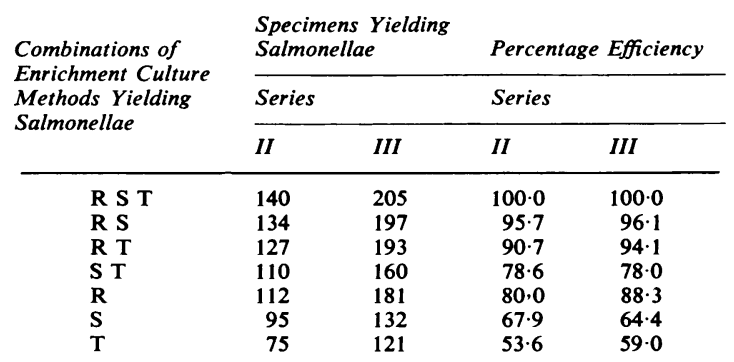

$\mathbf{R}=$ Rappaport $\mathbf{S}=$ selenite $; \mathbf{T}=$ tetrathionate.

Table II shows the comparison between the methods of enrichment culture in recovery of Salm. typhi from faecal specimens. Selenite broth, with 21 successes out of a possible $22(95.5 \%)$ positive specimens, was greatly superior to tetrathionate broth Difco $9(40.9 \%)$ and to Rappaport medium $12(54.5 \%)$.

Comparisons between isolations by the different 
TABLE II

COMPARISON OF METHODS OF ENRICHMENT CULTURE IN 22 ISOLATIONS OF Salm. typhi FROM FAECES

\begin{tabular}{|c|c|c|c|c|c|c|c|c|c|c|c|c|c|c|}
\hline \multirow{2}{*}{$\begin{array}{l}\text { Specimen } \\
\text { Method of culture } \\
\text { Isolations }\end{array}$} & \multicolumn{4}{|c|}{ Direct Culture Negative } & \multicolumn{4}{|c|}{ Direct Culture Positive } & \multicolumn{2}{|l|}{ Total } & \multicolumn{4}{|c|}{ Positive } \\
\hline & $\begin{array}{l}\text { RST } \\
5 \\
10 \cdot 00\end{array}$ & $\begin{array}{l}\mathbf{R} \\
\mathbf{0} \\
\mathbf{0} \cdot \mathbf{0}\end{array}$ & $\begin{array}{c}S \\
5 \\
100 \cdot 0\end{array}$ & $\begin{array}{c}T \\
1 \\
20 \cdot 0\end{array}$ & $\begin{array}{l}D \\
17 \\
100 \cdot 0\end{array}$ & $\begin{array}{l}R \\
12 \\
70 \cdot 6\end{array}$ & $\begin{array}{l}S \\
16 \\
94 \cdot 1\end{array}$ & $\begin{array}{l}T \\
8 \\
47 \cdot 1\end{array}$ & $\begin{array}{l}\text { DRST } \\
22 \\
100 \cdot 0\end{array}$ & $\begin{array}{l}\text { RST } \\
21 \\
95 \cdot 5\end{array}$ & $\begin{array}{l}R \\
12 \\
54 \cdot 5\end{array}$ & $\begin{array}{l}S \\
21 \\
95 \cdot 5\end{array}$ & $\begin{array}{l}T \\
9 \\
40.9\end{array}$ & $\begin{array}{l}D \\
17 \\
77 \cdot 3\end{array}$ \\
\hline
\end{tabular}

$\mathbf{R}=$ Rappaport $\mathbf{S}=$ selenite $\mathbf{T}=$ tetrathionate $\mathbf{D}=$ direct plate culture.

TABLE III

COMPARISON OF ISOLATIONS OF SALMONELLAE FROM 407 FAECES SPECIMENS DILUTED $1: 1,000$ AND UNDILUTED SERIES I

\begin{tabular}{|c|c|c|c|c|c|c|c|c|c|c|c|}
\hline \multirow{2}{*}{$\frac{\text { Specimens }}{\text { Method of culture }}$} & \multicolumn{5}{|c|}{ Diluted $1: 1,000$} & \multicolumn{5}{|c|}{ Undiluted } & \multirow[t]{2}{*}{ Total } \\
\hline & DRST & $\mathbf{R}$ & $\mathbf{S}$ & $\mathbf{T}$ & $\mathbf{D}$ & DRST & $\mathbf{R}$ & $\mathbf{S}$ & $\mathbf{T}$ & $\mathbf{D}$ & \\
\hline Isolations & 22 & 22 & 16 & 8 & 10 & 28 & 28 & 18 & 11 & 11 & 32 \\
\hline Percentage relative efficiency & $68 \cdot 8$ & $68 \cdot 8$ & $50 \cdot 0$ & $25 \cdot 0$ & $31 \cdot 3$ & $87 \cdot 5$ & $87 \cdot 5$ & $56 \cdot 3$ & $34 \cdot 4$ & $34 \cdot 4$ & $100 \cdot 0$ \\
\hline
\end{tabular}

$\mathbf{R}=$ Rappaport $; \mathbf{S}=$ selenite $\mathbf{T}=$ tetrathionate $\mathbf{D}=$ direct plate culture.

methods of enrichment culture and the diluted or undiluted inoculum are made in Table III. Of 407 specimens (series 1 ) yielding a total of 32 isolations of Salmonellae, $28(87.5 \%)$ were obtained from undiluted faeces compared with $22(68.8 \%)$ from faecal material diluted $1: 1,000$.

\section{DISCUSSION}

The results of this investigation have demonstrated the superiority of Rappaport medium for the isolation of Salmonellae from faeces, thereby extending the work reported by Iveson et al. (1964) on desiccated coconut. The relative efficiency of Salmonella isolations for Rappaport medium in the two series was $91.0 \%$ and $88.1 \%$ respectively, in contrast to $\mathbf{7 5 . 2} \%$ and $\mathbf{7 8 . 8} \%$ for selenite broth, $70.3 \%$ and $70.0 \%$ for tetrathionate broth, and $36.5 \%$ and $46.1 \%$ for direct culture. Using a combination of selenite and Rappaport media, $96.9 \%$ and $96.6 \%$ of all isolations, in series II and III respectively, were achieved.

However, these figures, while holding good for the Salmonella strains listed, were inapplicable to the isolations of Salm. typhi from faeces. The relative efficiency of Rappaport's medium at $54.5 \%$ compared unfavourably with selenite broth at $95.5 \%$ efficiency, but was still superior to tetrathionate at $40.9 \%$. This finding was in agreement with the reports of Rappaport et al. (1956) and of Anderson and Kennedy (1965). In addition, it may be noted that Salm. cholerae suis was not isolated during these investigations, and the comparative performance of Rappaport's medium in the recovery of this difficult selenite-sensitive serotype remains to be evaluated. The problems of Salm. cholerae suis isolation have been reported by Williams Smith (1952 and 1959).

While Rappaport et al. (1956) and Thomson (1954) reported favourably on the isolation of Salmonella from dilute faeces the findings reported here are more in agreement with those of Collard and Unwin (1958) and Dixon (1961) where the superiority of methods involving the inoculation of media with undiluted faeces, as opposed to diluted faeces, was reported. This study showed that the relative efficiency in the isolation of salmonellae from 407 faecal specimens examined was $87.5 \%$ for undiluted and $68.8 \%$ for $1: 1,000$ dilution of faeces.

It is clear from the above results that, while the greater the number of enrichment methods employed the higher will be the rate of recovery of Salmonellae from faecal specimens, the use of Rappaport's magnesium chloride malachite green will provide the greatest chance of success in the isolation of a wide variety of Salmonella serotypes when a single method only is employed. However, the relative inefficiency of Rappaport medium in the recovery of Salm. typhi requires the additional use of selenite broth to ensure wide coverage.

The authors are indebted to Dr. Joan Taylor, Director, Salmonella Reference Laboratory, Central Public Health Laboratories, Colindale, London, for examining and confirming the Salmonella serotypes; to Mrs. E. Eksteins and Miss N. Kulbach for technical assistance, and to Dr. W. S. Davidson, Commissioner of Public Health, Western Australia, for permission to publish these results.

\section{REFERENCES}

Anderson, K., and Kennedy, H. (1965). J. clin. Path., 18, 747.

Collard, P., and Unwin, M. (1958). Ibid., 11, 426.

Dixon, J. M. S. (1961). Ibid., 14, 397. 
Hajna, A. A., and Damon, S. R. (1956). Appl. Microbiol., 4, 341. Hobbs, B. C., and Allison, V. D. (1945). Mth. Bull. Minist. Hlth Lab. Serv., 4, 63.

Hooper, W. L., and Jenkins, H. R. (1965). J. Hyg. (Lond.), 63, 491. Iveson, J. B., Kovacs, N., and Laurie, W. (1964). J. clin. Path., 17, 75. Kauffmann, F. (1930). Zbl. Bakt., I Abt. Orig., 119, 148. (1935). Z. Hyg. Infekt.-Kr., 117, 26.

Kovacs, N. (1963). Yearly Report, Public Health Laboratory, Perth W. Australia.

Lang, K. (1960). Zbl. Bakt., I Abt. Orig., 180, 221.

Leifson, E. (1936). Amer. J. Hyg., 24, 423.
Müller, L. (1923). C. R. Soc. Biol. (Paris), 89, 434.

Preuss, H. (1949). Z. Hyg. Infekt.-Kr., 129, 187.

Rappaport, F., Konforti, N., and Navon, B. (1956). J. clin. Path., 9, 261.

Rolfe, V. (1946). Mth. Bull. Minist. Hlth Lab. Serv., 5, 158.

Sachs, A. (1939). J. roy. Army med. Corps, 73, 235.

Sen, R. (1964). Indian J. Path. Bact., 7, 93.

Smith, H. Williams (1952). J. Hyg. (Lond.), 50, 21.

- (1959). Ibid., 57, 266.

Thomson, S. (1954). Ibid., 52, 67.

Zajc-Satler, J., and Banic, S. (1965). J. clin. Path., 18, 750. 